\title{
PHYSICO-CHEMICAL PROPERTIES OF CORN-BASED SNACK FORTIFIED WITH RASPBERRY SEEDS
}

\author{
Jelena N. Perović*, Boško D. Marić, Nemanja V. Teslić, Jovana S. Kojić, Jelena A. Krulj,
} Bojana V. Filipčev, Nebojša M. Ilić, Marija I. Bodroža Solarov

University of Novi Sad, Institute of Food Technology, 21000 Novi Sad, Bul. cara Lazara 1, Serbia

\author{
*Corresponding author: \\ Phone: +381214853751 \\ E-mail address: jelena.perovic@fins.uns.ac.rs
}

\begin{abstract}
This study was carried out in order to evaluate the effect of extrusion conditions on the physico-chemical properties of corn grits-raspberry seeds snacks. The raspberry seeds were chosen to fortify the corn-based snack due to their richness in ellagic acid, a natural phenol antioxidant which has a beneficial effect on human health. Extrudates were prepared using a laboratory single-screw extruder, operated at different conditions. Box-Behnken experimental design was used to evaluate the impact of processing variables: moisture content (18-25\%), temperature of extrusion $\left(100-200^{\circ} \mathrm{C}\right)$ and content of raspberry seeds $(0-20 \%)$ on expansion index, hardness and ellagic acid content. Snack with the highest expansion (2.15) was obtained under $18 \%$ moisture, $150{ }^{\circ} \mathrm{C}$ temperature and $0 \%$ of raspberry seeds content. The highest content of ellagic acid $(609.54 \mathrm{mg} / \mathrm{kg})$ was reported in the samples with $20 \%$ of raspberry seeds, $100{ }^{\circ} \mathrm{C}$ temperature and $21.5 \%$ moisture. Extrudates obtained under conditions of $0 \%$ raspberry seeds, $100{ }^{\circ} \mathrm{C}$ temperature and $21.5 \%$ moisture showed the highest hardness value $(53.34 \mathrm{~kg})$. It was concluded that changing one or more parameters in the extrusion process can significantly affect the characteristics of the obtained product, and that raspberry seeds have a great potential in food fortification.
\end{abstract}

Key words: corn grits, raspberry seeds, extrusion, ellagic acid, expansion index, hardness

\section{INTRODUCTION}

Extrusion-cooking is a well-known technology for the production of a variety of food products, in example cereal-based snacks, ready-to-eat cereals, dry pet foods, baby foods, meat and cheese analogues (Ding et al., 2005; Navale et al., 2015). Miller and Mulvaney (2000) noted that the final product quality depends on extrusion parameters such as: raw materials characterristics, feed moisture, process temperature, screw speed, type of screw configuration, and others. Snack foods have become an important part of the human diet and have influence on overall nutrition (Rodríguez-Miranda et al., 2011). According to Singh et al. (2007) cereals are an excellent choice for extrusion due to their high starch content. Corn grits is the most commonly used ingredient for extruded foods, such as ready-to-eat breakfast cereals and snacks (Gujral et al., 2001). Since extrusion allows mixing of various ingredients, this process is suitable for forming new functional foods (Brennan et al., 2013). Importance of the extrusion process is linked to the utilization of by-products of the food industry with potential bioactivity and nutritional properties. Stojceska et al. (2009) investigated the impact of different extrusion cooking conditions on the quality of ready-to-eat snack made from food by-products such as brewer's 
spent grain and red cabbage trimmings. Seeds are the main by-product during processing of berries.

Berry fruits are rich in compounds that show numerous biological activity, such as ellagitannins, flavonoids and phenolic acids (Szajdek and Borowska, 2008; Juranic et al., 2005, Mullen et al., 2002; Wada et al. 2002; Zafrilla et al., 2001). Nile and Park (2014) reported that berry seeds are health-beneficial by-product. Elagitanins showed good potential for the vascular health benefits and for the management of hyper-glycemia (Larrosa et al., 2010; Da Silva Pinto et al., 2010). There is a particular interest in the amounts of ellagic acid in these fruits because of its antioxidant, antihepatotoxic, antisteatosic, anticholestatic, antifibrogenic, antihepatocarcinogenic, antiviral (García-Niño and Zazueta, 2015), anti-inflammatory (Kassim et al., 2010), antitumor, antimetastatic, antiangiogenic (Ceci et al., 2018) and antiproliferative activity (Han et al., 2006). Highlighting these positive properties, raspberry seeds may be used in food production as an ingredient in muffins, yogurt and other products (Yu and Moore, 2007).

Besides that, Serbia is the third largest producer of raspberries in the world with the production of approximately 100000 tons per year (FAOSTAT, 2017).

According to Daniel et al. (1989), the raspberry seeds contain $87.8 \%$ of the ellagic acid more than in raspberry pulp. Another importance of incorporating raspberry seeds into new food products is a contribution to continuous endeavor for a sustainable system and the utilization of by-products of the food industry.

The aim of this study was to determine the effect of different extrusion conditions on the physico-chemical properties of corn grits-raspberry seeds snacks. By varying extrusion temperature, moisture content of corn grits-raspberry seeds mixture and content of raspberry seeds, 15 products were obtained. Additionally, the purpose of this study was to investigate possible changes in ellagic acid content as affected by extrusion under different conditions.

\section{MATERIALS AND METHODS}

\section{Plant materials}

Corn grits was produced by "Mirotin Tisa" d.o.o., Savino selo, Serbia and delivered in the original package. Raspberry seeds were provided by "Mondi Lamex", Kraljevo, Serbia and milled on a cooling mill (Knifetec $^{T M}$ 1095, FOSS, Denmark) in order to provide uniform particle size distribution. Both corn grits and raspberry seeds were sieved using a sieve with 0.5-1 $\mathrm{mm}$ opening diameter, to achieve as uniform granulation as possible prior to the extrusion process.

\section{Extrusion process}

Extrusion process was performed on a single-screw laboratory extruder (Model GNF 1014/2, Type 110513, Brabender, Duisburg, Germany). Screw speed was constant at $150 \mathrm{rpm}$ and a $3 \mathrm{~mm}$ diameter die was used. The feed and compression zone temperatures were maintained at 50 ${ }^{\circ} \mathrm{C}$ and $75^{\circ} \mathrm{C}$, respectively, while die zone temperature was kept either at 100, 150 and $200{ }^{\circ} \mathrm{C}$. Jaekel et al. (2015) and Kapelko et al. (2013) who performed cassava starch and potato starch extrusion on the same single-screw laboratory extruder as in this study, set similar extrusion zone temperatures (first zone $50{ }^{\circ} \mathrm{C}$, second zone $70{ }^{\circ} \mathrm{C}$ and die zone $70{ }^{\circ} \mathrm{C}$; first zone $60{ }^{\circ} \mathrm{C}$, second zone $65^{\circ} \mathrm{C}$ and die zone 70 ${ }^{\circ} \mathrm{C}$, respectively). Box-Behnken experimental design (Table 1) was used to evaluate the impact of three processing variables: moisture content (18-25\%), temperature of extrusion $\left(100-200{ }^{\circ} \mathrm{C}\right)$ and content of raspberry seeds $(0-20 \%)$.

\section{The expansion index of the snack pro- duct}

The diameter of the 20 granules was measured by a movable, beam gauge (MIB Messzeuge $\mathrm{GmbH}$, Spangenberg, Germany). The expansion index (EI) is calculated as the ratio of the diameter of extrudates and the diameter of the die.

\section{The hardness of the snack product}

The hardness of snack product was determined by diametric compression on the device TA-XT2 Texture Analyzer (Stable Micro Systems, Surrey, UK) according to 
the method described by Svihus et al. (2004).

From each sample, two individual extrudates were placed horizontally on a flat surface of the device, and then compressed with a $45 \mathrm{~mm}$ stainless steel cylinder probe, at a load of $50 \mathrm{~kg}$ and trigger force of $100 \mathrm{~g}$. Hardness represents the force at which the first break of the extrudate occurs, which represents the maximum on the obtained curve of the dependence of force from time. The hardness of the sample was expressed as the mean value of 15 measurements. The instrument setting parameters during the test were as follows: speed before measurement - 2.0 $\mathrm{mm} / \mathrm{sec}$; measuring speed - $1 \mathrm{~mm} / \mathrm{sec}$; speed after measurement - $10 \mathrm{~mm} / \mathrm{sec}$, probe path: $2.5 \mathrm{~mm}$.

\section{Quantification of ellagic acid using HPLC}

Considering that content of free ellagic acid is low, hydrolysis was required to convert ellagitannins to ellagic acid. Ellagic acid (EA) was determined after acidic hydrolysis using a modified method described by Bobinaite et al. (2012).

Raspberry seeds supplemented snacks were milled and homogenized using cooling mill (Knifetec ${ }^{\mathrm{TM}}$ 1095, FOSS, Denmark). Then $1.5 \mathrm{~g}$ of the sample was mixed with $1.5 \mathrm{ml}$ of acidified methanol (final contraction $2 \mathrm{M}$ of $\mathrm{HCl}$ ). The prepared solutions were placed in an ultrasound bath for 30 minutes and then set to hydrolysis for $2 \mathrm{~h}$ at $85^{\circ} \mathrm{C}$. The samples were then cooled at ambient temperature and made up to $3 \mathrm{ml}$ with methanol. All samples were filtered using cellulose $0.45 \mu \mathrm{m}$ filters prior to HPLC analysis.

Identification and determination of ellagic acid in extracts were performed by HPLC (HP-1260, Agilent Technologies Inc., USA) with Diode-Array detector, using RP-C18 column (ZORBAX Eclipse XDB-C18, 1.8Micron, $50 \times 4.6 \mathrm{~mm})$. The mobile phase was a mixture of acetonitrile $(A)$ and $0.1 \%$ formic acid solution (B). The flow rate of mobile phase was $0.5 \mathrm{ml} / \mathrm{min}$ with an elution gradient: $0-6 \mathrm{~min}$. $15 \% \mathrm{~A}, 85 \% \mathrm{~B}$; $6-28 \min 50 \%$ A, 50\% B. The DAD acquisition wavelength was performed at 254 $\mathrm{nm}$. An external calibration method, using ellagic acid (Sigma Aldrich, Steinheim, Germany) as standard was used. The stock solution was diluted to obtain 5-100 ppm concentration working solution range $(\mathrm{R}=0.9997)$.

\section{Statistical analysis}

The Box-Behnken experimental design with three independent variables comprised 15 experiments with three replicates at the central point. Independent variables used in experimental design were moisture value (A, 18-25\%), temperature $\left(\mathrm{B}, 100-200{ }^{\circ} \mathrm{C}\right)$ and raspberry seeds content $(\mathrm{C}, 0-20 \%)$, while response variables were expansion index $(\mathrm{EI})$, hardness $(\mathrm{kg})$ and ellagic acid content $(\mathrm{mg} / \mathrm{kg})$. The data obtained from those experiments was statistically analyzed by analysis of variance (ANOVA). Design-Expert (version 11) was employed for statistical and modelling data processing using second-order model of a polynomial (SOP) and response surface methodology. The model adequacy and fitting were evaluated with following criteria: the significance of the model according to the $p$-value, lack of fit and regression coefficient $\left(r^{2}\right)$ values.

\section{RESULTS AND DISCUSSION}

Expansion index, hardness and content of ellagic acid are very important parameters in order to define the quality of the final snack product. Obtained results for these parameters are presented in Table 1.

\section{The expansion index of the snack product}

The expansion index (EI) of the extruded snack products is the most important parameter in terms of their acceptability by consumers. The highest $\mathrm{El}$ value (2.15) was observed using the lowest moisture content $(18 \%)$ and the higher temperature $\left(150{ }^{\circ} \mathrm{C}\right)$, while the lowest $\mathrm{El}$ value $(0.94)$ was noticed at the minimal temperature $\left(100{ }^{\circ} \mathrm{C}\right)$ and the highest moisture content (25\%). These results are in accordance with Ding et al. (2006) who found that the increase in the moisture content of the input material leads to a great reduction of wheat-based extrudate expansion. Hagenimana et al. (2006) consider that the influence of moisture on the $\mathrm{El}$ can be explained by the fact that the dough during 
Table 1.

Physico-chemical properties of corn grits extruded at different conditions

\begin{tabular}{cccccc}
\hline $\begin{array}{c}\text { Mixture } \\
\text { moisture } \\
\text { content \% }\end{array}$ & $\begin{array}{c}\text { Temperature of } \\
\text { extrusion }\left({ }^{\circ} \mathbf{C}\right)\end{array}$ & $\begin{array}{c}\text { Raspberry } \\
\text { seed content (\%) }\end{array}$ & $\begin{array}{c}\text { Expansion } \\
\text { Index }\end{array}$ & $\begin{array}{c}\text { Hardness } \\
\mathbf{( k g )}\end{array}$ & $\begin{array}{c}\text { Ellagic Acid } \\
\mathbf{( m g / k g )}\end{array}$ \\
\hline 18 & 100 & 10 & 2.05 & 45.32 & 290.3 \\
25 & 100 & 10 & 0.94 & 39.63 & 263.9 \\
18 & 200 & 10 & 2.10 & 30.72 & 319.2 \\
25 & 200 & 10 & 1.52 & 33.20 & 235.3 \\
18 & 150 & 0 & 2.15 & 33.93 & 0 \\
25 & 150 & 0 & 1.51 & 40.12 & 0 \\
18 & 150 & 20 & 1.67 & 50.76 & 585.8 \\
25 & 150 & 20 & 1.33 & 18.43 & 579.3 \\
21.5 & 100 & 0 & 1.14 & 53.34 & 0 \\
21.5 & 200 & 0 & 1.69 & 27.24 & 0 \\
21.5 & 100 & 20 & 1.05 & 40.65 & 609.5 \\
21.5 & 200 & 20 & 1.46 & 34.74 & 527.5 \\
21.5 & 150 & 10 & 1.78 & 43.55 & 281.4 \\
21.5 & 150 & 10 & 1.73 & 41.06 & 280.9 \\
21.5 & 150 & 10 & 1.75 & 43.92 & 276.9 \\
\hline
\end{tabular}

Table 2.

Variance analysis for the expansion index (EI), for a second-order model of a polynomial

\begin{tabular}{cccl}
\hline Members & SE & $\boldsymbol{F}$ & $\boldsymbol{p}$ \\
\hline$A$ & 0.048 & 48.93 & $0.0009^{*}$ \\
$B$ & 0.048 & 17.37 & $0.0088^{*}$ \\
$C$ & 0.048 & 6.49 & $0.0514^{* * *}$ \\
$A^{2}$ & 0.70 & 2.66 & 0.1639 \\
$B^{2}$ & 0.70 & 9.19 & $0.0290^{* *}$ \\
$C^{2}$ & 0.70 & 8.42 & $0.0337^{* *}$ \\
$A B$ & 0.68 & 3.86 & 0.1066 \\
$A C$ & 0.68 & 1.27 & 0.3112 \\
$B C$ & 0.68 & 0.27 & 0.6265 \\
\hline Model & & & 0.0360 \\
Lack of fit & 0.090 & & \\
Pure error & 0.0013 & & \\
$r^{2}$ & 0.8651 & & \\
\hline F- Fisher test; $p-p$ value; ${ }^{*}$ statistically significant at $p<0.01 ;{ }^{* *}$ statistically significant at $p<0.05 ;{ }^{* * *}$ statistically \\
significant at $p<0.10 ;$ A-Moisture (\%); B-Temperature ( ${ }^{\circ}$ C); C-Raspberry seed content (\%)
\end{tabular}

the extrusion with higher moisture content produces lower vapor pressure (probably due to the reduction of the temperature in the barrel), which leads to a reduction in expansion. Kristiawan et al. (2016) reported that increasing moisture content can soften the amylopectin structure and reduce the elastic properties of the dough leading to a reduction in extrudate expansion.

Kaur et al. (2015) noted the trend of increasing expansion index with increasing extrusion temperature in corn extrudates. As Thymi et al. (2005) discussed, extrusion temperature affects various properties of starch, including corn grits starch. They also reported that I ncreasing melt temperature significantly increased the expansion ratio values for all the examined feed moisture contents. Robin et al. (2011) concluded that the increase in expansion index with increasing extrusion temperature in barrel may be explained by the changing of viscoelastic properties of melted starch in the extruder.

According to Zhu et al. (2010) different temperatures may affect degree of starch gelatinization, and also have an impact on expansion of extrudates. Thachil et al. (2013) noticed that the expansion mostly depends on the content of amylose, and increasing the share of raspberry seeds reduces the share of corn grits rich in starch and thus reduces the expansion of 
the snack. Increased temperature reduced the expansion index in our study. The obtained results are in agreement with Kosmala et al. (2015) and with the fact that raspberry seeds are rich in dietary fibers. Li et al. (2005) concluded that the addition of dietary fiber to corn flour caused lower expansion and greater hardness than those of the control material.

In the SOP model, the greatest impact for calculating the EI had linear members $A$ and $B$, statistically significant at $p<0.01$, which corresponds to Filli et al. (2012) and Kaur et al. (2015). Their investigations showed that there are statistically significant effects of the linear moisture content of the starting material and temperature of extrusion to the degree of expansion. Linear $C$ was statistically significant in this SOP model at $p<0.1$. The square members $\mathrm{B}^{2}$ and $\mathrm{C}^{2}$ of the SOP polynomial were statistically significant at $p<0.05$. Other product members in the SOP model did not show any statistical significance. The calculated value of the coefficient of determination of the SOP model $\left(r^{2}\right)$, as well as the calculated error value of the model (close to zero, which implies little or no effect on model formation), guarantees a good and reliable predictor of the El for the extrusion process, as well as the good fitting of the SOP model values with experimental data for El extruded (Table 2). Visual analysis of surface plots (Figure 1) is consistent with multiple regression analysis. It is noticeable that the temperature and moisture content dominantly influence response comparing to other variables, by analyzing the slopes for each variable.
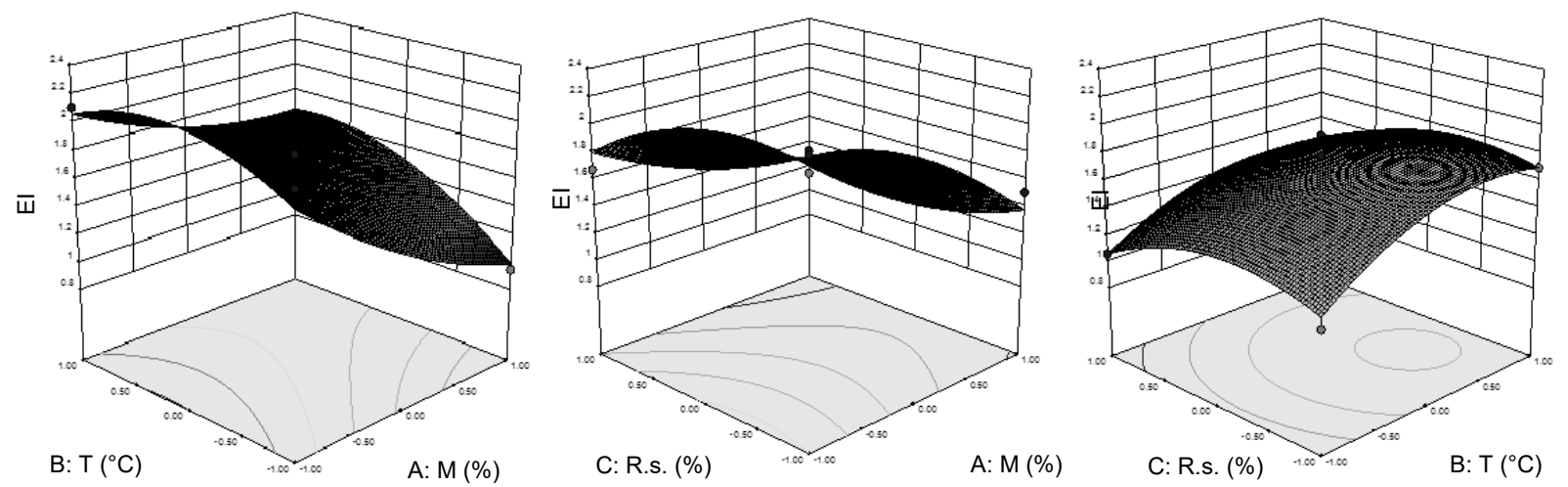

Figure 1. Response surface plots showing combined effects of process variables respectively: temperature $\left(\mathrm{T},{ }^{\circ} \mathrm{C}\right)$ and moisture $(\mathrm{M}, \%)$, raspberry seeds content (R.s., \%) and moisture (M, \%), and raspberry seeds content (R.s., \%) and temperature $\left(\mathrm{T},{ }^{\circ} \mathrm{C}\right)$, on expansion index (EI)
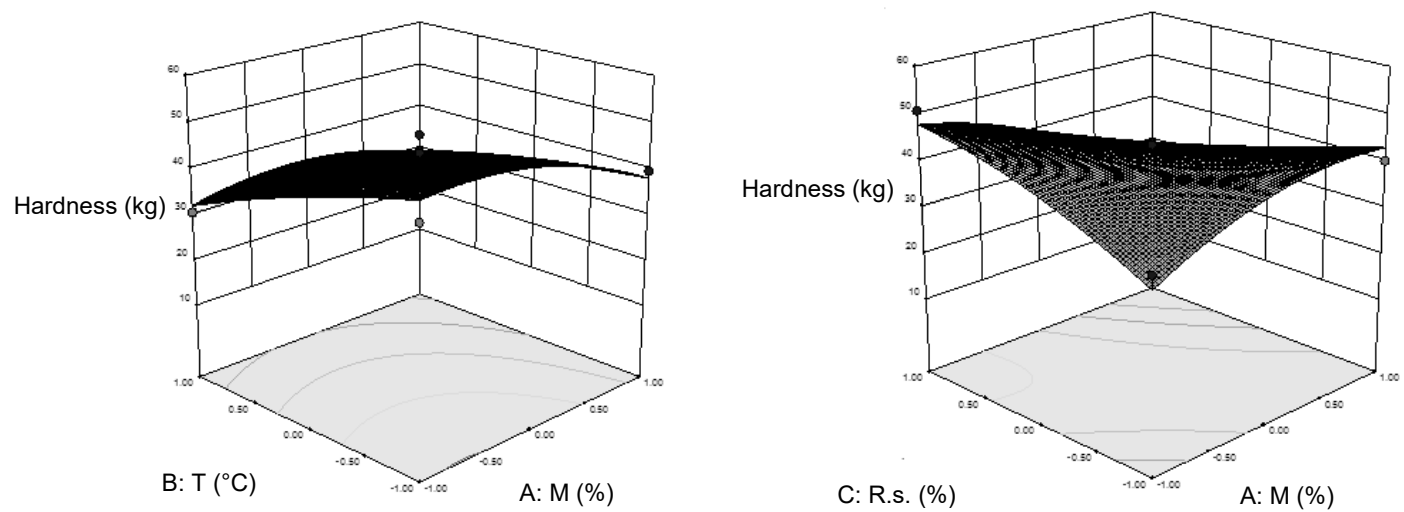

Figure 2. Response surface plots showing combined effects of process variables respectively: temperature $\left(\mathrm{T},{ }^{\circ} \mathrm{C}\right)$ and moisture (M, \%) and raspberry seeds content (R.s., \%) and moisture (M, \%) on hardness 
Table 3.

Variance analysis for the hardness, for a second-order model of polynomial

\begin{tabular}{cccc}
\hline Members & $\boldsymbol{S E}$ & $\boldsymbol{F}$ & $\boldsymbol{p}$ \\
\hline$A$ & 1.46 & 6.28 & $0.0541^{* * *}$ \\
$B$ & 1.46 & 20.52 & $0.0062^{*}$ \\
$C$ & 1.46 & 0.74 & 0.4301 \\
$A^{2}$ & 2.15 & 4.19 & $0.0960^{* * *}$ \\
$B^{2}$ & 2.15 & 0.32 & 0.5944 \\
$C^{2}$ & 2.15 & 1.49 & 0.2768 \\
$A B$ & 2.07 & 0.97 & 0.3691 \\
$A C$ & 2.07 & 21.65 & $0.0056^{*}$ \\
$B C$ & 2.07 & 5.94 & $0.0588^{* * *}$ \\
\hline Model & \multicolumn{3}{c}{0.0238} \\
\hline Lack of fit & 80.85 & & \\
Pure error & 4.83 & & \\
$r^{2}$ & 0.7896 & & \\
\hline F- Fisher test; $p-p$ value; ${ }^{*}$ statistically significant at $p<0.01 ;{ }^{* *}$ statistically significant at $p<0.05 ;{ }^{* * *}$ statistically \\
significant at $p<0.10 ;$ A-Moisture (\%); B-Temperature $\left({ }^{\circ}\right.$ C); C-Raspberry seed content (\%)
\end{tabular}

\section{Hardness}

The highest hardness value $(53.34 \mathrm{~kg})$ was obtained with $21.5 \%$ moisture, $100{ }^{\circ} \mathrm{C}$ and $0 \%$ raspberry seeds. The lowest hardness value $(18.43 \mathrm{~kg})$ was obtained by conditions of $25 \%$ moisture content, 150 ${ }^{\circ} \mathrm{C}$ and $20 \%$ raspberry seeds. It was noticed that hardness increased with decreasing moisture content of the initial material. Lazou and Krokida (2010) came to the same conclusion that the hardness of the extrudate based on corn grits with lens reduces by increasing the moisture content of the initial material. They also reported that temperature rise produced more expanded snacks with softer texture. Results for raspberry seeds supplemented snacks are in agreement with the research of Anton et al. (2009), who concluded that the textural properties are very dependent on the degree of expansion.

The greatest impact on hardness in the SOP model (Table 3 ) had linear members A (statistically significant at $p<0.10$ ), B (statistically significant at $p<0.01$ ), and interactions $A C$ (statistically significant at $p$ $<0.01$ ), BC (statistically significant at $p$ $<0.10$ ) and quadratic member $A^{2}$ (statistically significant at $p<0.10$ ). These results correspond to Ding et al. $(2005,2006)$ who reported that there are statistically significant effects of the linear moisture content of the starting material to the hardness of final rice and wheat extrudates. Feed moisture content increased modulus of elasticity of corn extrudates and led to the plastification of the sample. Lazou and Krokida (2010) explained that the decrease of moisture content in extrusion cooking tends to increase specific mechanical energy, and consequently to favor macromolecular degradation of starch though dextrinization. Kumar et al. (2010) noted that the decrease in hardness with increase of temperature might be due to higher expansion at elevated temperatures. Raspberry seeds addition affected expansion ratio negatively, as well as increased hardness of the final products. As Chiu et al. (2012) reported, fibers contained in materials used to supplement extrudates could have imparted structural integrity to the extrudate, resulting in higher value of hardness, which was also confirmed with our results.

Visual analysis of surface plots (Figure 2) is consistent with multiple regression analysis. It is noticeable that the temperature and moisture content and interaction of these parameters with raspberry seeds content dominantly influenced response comparing to other variables, by analyzing the slopes for each variable.

\section{Ellagic acid content}

Ellagic acid is a highly thermostable molecule with a melting point of $450{ }^{\circ} \mathrm{C}$ and a boiling point of $796.5{ }^{\circ} \mathrm{C}$ (Muthukumaran et al., 2011). Usta et al. (2013) considered that ellagic acid is a very interesting phy- 
tochemical compound for the development of foods and nutraceuticals because of its relatively stability under physiological conditions in the stomach. Pure, crystalline ellagic acid is sparingly soluble in water $(9.3 \mu \mathrm{g} / \mathrm{ml}$ at $\mathrm{pH} 7.4)$ and in alcohol (O'Neil, 2006; Landete, 2011).

Content of total ellagic acid ranged from 0 $\mathrm{mg} / \mathrm{kg}$ in the extrudates without raspberry seeds, to $609.54 \mathrm{mg} / \mathrm{kg}$ in the samples containing $20 \%$ of raspberry seeds and extrusion conditions of $21.5 \%$ moisture content and $100{ }^{\circ} \mathrm{C}$. These results are in accordance with facts that raspberry seeds have been reported as good source of ellagic acid (Daniel et al., 1989).

Paredes-López et al. (2010) noted that there is a growing interest in utilization of berry fruits due to antioxidant activity and health-promoting properties of their phenolics. Raspberries are rich in antho-cyanins, flavonols, and ellagic acid deriva-tives (Rios de Souza et al., 2014). Juranic et al. (2005) reported that the antiproliferative action of raspberry seeds extracts was correlated with its content of ellagic acid. According to Harris et al. (2001) and Daniel et al. (1989) black raspberries contain approximately $2 \mathrm{mg}$ of ellagic acid per gram dry weight, and this acid is primarily found in the seeds of the berry in form of ellagitannins, while pulp contains only 0.1 $\mathrm{mg} / \mathrm{g}$ dry weight.

The greatest influence on calculating the content of ellagic acid in the SOP model (Table 4) had a linear member $C$ statistically significant at $p<0.01$ whereas other model coefficients did not have any statistical significance. This conclusion was expected because of the natural presence of ellagic acid in raspberry seeds. According to Bushman et al. (2004) red rasp- berry seeds contain $8.7 \mathrm{mg} / \mathrm{g}$ seeds of ellagic acid. Comparing the samples obtained under conditions of $25 \%$ moisture, $150{ }^{\circ} \mathrm{C}, 0 \%$ raspberry seed and $21.5 \%$ moisture, $200{ }^{\circ} \mathrm{C}, 20 \%$ raspberry seeds, it can be noticed that expansion index and hardness of these snacks are only slightly different. This led to conclusion that increased ellagic acid content did not affect the physical properties of snacks and therefore it might not be expected to diminish the product acceptability.

Processing can significantly affect the fruit phenolic content and their health-promoting properties. Thus, industrial processing of strawberries to obtain jams decreased the total ellagic content by $20 \%$ (Hakkinnen et al., 2000). Several extrusion process variables such as barrel temperature, pressure, screw speed, moisture content, flow rate, energy input, residence type, screw configuration and other can influence the composition and physicochemical properties of final products (Brennan et al., 2011). Many studies reported negative impact of extrusion process on polyphenol content and antioxidant activity in different snack products (Korus et al., 2007; Delgado-Licon et al., 2009). Table 5 shows percent of reduction in ellagic acid content in the raspberry seeds-supplemented snacks after extrusion process under different conditions.

According to Yağci and Göğüs (2010), feed moisture content and barrel temperature are the most significant process variables which decrease the total phenolic content in an extrudate. High moisture content and high barrel temperature may cause decarboxylation of phenolic acids during extrusion, and lead to polymerrization of phenols which results in re-

Table 4.

Variance analysis for ellagic acid (EA) content, for a second-order model of a polynomial

\begin{tabular}{cccc}
\hline Member & SE & $\boldsymbol{F}$ & $\boldsymbol{p}$ \\
\hline$A$ & 11.59 & 0.38 & 0.5524 \\
$B$ & 11.59 & 0.055 & 0.8187 \\
C & 11.59 & 616.68 & $<0.0001^{*}$ \\
\hline Model & & & $<0.0001$ \\
\hline Lack of fit & 2867.19 & & \\
Pure error $r^{2}$ & 1408.73 & & \\
\hline F- Fisher test; $p$ - $p$ value; *statistically significant at $p<0.01$ & &
\end{tabular}


Table 5.

Reduction of EA content in raspberry seeds supplemented snacks after extrusion process under different conditions (calculated on dry matter content)

\begin{tabular}{cccc}
\hline $\begin{array}{c}\text { Moisture content of } \\
\text { mixture } \%\end{array}$ & $\begin{array}{c}\text { Temperature of } \\
\text { extrusion }\left({ }^{\circ} \mathbf{C}\right)\end{array}$ & $\begin{array}{c}\text { Raspberry } \\
\text { seed content (\%) }\end{array}$ & $\begin{array}{c}\text { Reduction of ellagic } \\
\text { acid content (\%) }\end{array}$ \\
\hline 18 & 100 & 10 & 7.06 \\
25 & 100 & 10 & 19.85 \\
18 & 200 & 10 & 3.29 \\
25 & 200 & 10 & 28.58 \\
18 & 150 & 0 & 0 \\
25 & 150 & 0 & 0 \\
18 & 150 & 20 & 10.56 \\
25 & 150 & 20 & 14.06 \\
21.5 & 100 & 0 & 0 \\
21.5 & 200 & 0 & 0 \\
21.5 & 100 & 20 & 9.72 \\
21.5 & 200 & 20 & 22.18 \\
21.5 & 150 & 10 & 14.96 \\
21.5 & 150 & 10 & 14.81 \\
21.5 & 150 & 10 & 16.08 \\
\hline
\end{tabular}

duced extractability and antioxidant activity (Repo-Carrasco-Valencia et al. 2009a, Repo-Carrasco-Valencia et al., 2009b). Similar trend was observed in this study since the highest reduction of ellagic acid $(28.58 \%)$ was noticed in the sample with $10 \%$ of raspberry seeds extruded at $25 \%$ moisture content and $200{ }^{\circ} \mathrm{C}$ whereas the lowest ellagic acid reduction (3.29\%) was reported in the sample with $10 \%$ raspberry seeds, processed at $18 \%$ moisture content and $200{ }^{\circ} \mathrm{C}$, however, the overall effect of moisture content on EA variation was found statistically insignificant in the SOP model.

One might argue that the acidic hydrolysis step prior to analysis of EA might hinder the effect of extrusion parameters on variation in $E A$ content due to high sensitivity of phenolic compounds to $\mathrm{pH}$ changes. Therefore, in further research, it would be advisable to determine free and bound forms of EA to better reveal the fate of EA during processing. The hydrolysis step has been used in determination of total EA content due to the fact that, in raspberry seeds, as already mentioned, $E A$ is mainly present in its bound form, elagitannins. Bobinaite et al. (2012) measured the content of ellagic acid in 19 different raspberry cultivars before and after hydrolysis and reported ellagic acid content of $2.0 \pm 0.10$ to $5.5 \pm 0.09 \mathrm{mg} / 100 \mathrm{~g}$ fresh weight in free form and $83.9 \pm 6.7$ to $246.3 \pm 12.1 \mathrm{mg} / 100 \mathrm{~g}$ fresh weight after hydrolysis. Gođevac et al. (2009) and Landete (2011) reported that one of the main constituents after hydrolysis of raspberry seeds extract was ellagic acid.

\section{CONCLUSIONS}

Based on the obtained results, it can be concluded that different extrusion parameters affected the physico-chemical properties of final snack product. Higher moisture content of the input material led to greater reduction in the extrudate expansion and ellagic acid content, while hardness increased. Furthermore, higher temperature values resulted in higher expansion of extrudates and decreased hardness and ellagic acid content. The content of ellagic acid also depended on the content of raspberry seeds in each sample. Further investigations should focus on the optimization of the extrudate composition due to the fact that raspberry seeds have a great potential in food fortifycation.

\section{ACKNOLWLEDGEMENTS}

These results are part of the research carried out within the project of the Ministry of Science, Education and Technological Development of the Republic of Serbia, III 46005.

\section{REFERENCES}

1. Anton, A.A., Gary Fulcher, R., Arntfield, S.D. (2009). Physical and nutritional impact of fortification of corn starch-based extruded snacks 
with common bean (Phaseolus vulgaris L.) flour: Effects of bean addition and extrusion cooking. Food Chemistry, 113, 989-996.

2. Bobinaite, R., Viskelis, P., Rimantas Venskutonis, P. (2012). Variation of total phenolic, anthocyanins and radical scavenging capacity in various raspberry (Rubus spp.) cultivars. Food Chemistry, 132, 1495-1501.

3. Brennan, C., Brennan, M., Derbyshire, E., Tiwari, K.B. (2011). Effects of extrusion on the polyphenols, vitamins and antioxidant activity. Trends in Food Science and Technology, 22, 570-575.

4. Brennan, M., Derbyshire, E., Tiwari, B., Brennan, C. (2013). Ready-to-eat snack products: the role of extrusion technology in developing consumer acceptable and nutritious snacks. International Journal of Food Science and Technology, 48, 893-902.

5. Bushman, B.B., Phillips, B., Isabell, T., Ou, B., Crane, J.M., Knapp, S.J. (2004). Chemical composition of caneberry (Rubus spp.) seeds and oils and their antioxidant potential. Journal of Agriculture and Food Chemistry, 52 (26), 7982-7987.

6. Ceci, C., Lacal, P.M., Tenori, L., De Martino, M.G., Miano, R., Grazoani, G. (2018). Experimental evidence of the antitumor, antimetastatic and antiangiogenic activity of ellagic acid. Nutrients, 10, 1756.

7. Chiu, H.W., Peng, J-C., Tsai, S-J., Tsay, J-R., Lui, W-B. (2013). Process optimization by response surface methodology and characteristics investigation of corn extrudate fortified with yam (Dioscorea alata L.). Food and Bioprocess Technology, 6, 1494-1504.

8. Da Silva Pinto. M., De Carvalho. J.E., Lajolo. M., Genovese. M.I., Shetty. K. (2010). Evaluation of antiproliferative, anti-type 2 diabetes, and antihypertension potentials of ellagitannins from strawberries (Fragaria ananassa Duch.) using in vitro models. Journal of Medical Foods, 13 (5), 1027-1035.

9. Daniel, E.M., Krupnick, A.S., Heur, Y.H., Blinzler, J.A., Nims, R.W., Stoner, G.D. (1989). Extraction, stability, and quantitation of ellagic acid in various fruits and nuts. Journal of Food Composition and Analysis, 2, 338-349.

10. Delgado-Licon, E., Ayala, A.L. M., Rocha-Guzman, N.E., Gallegos-Infante, J.A., Atienzo-Lazos, M., Drzewiecki, J., Martínez-Sánchez, C.E., Gorinstein, S. (2009). Influence of extrusion on the bioactive compounds and the antioxidant capacity of the bean/corn mixtures. International Journal of Food Sciences and $\mathrm{Nu}$ trition, 60 (6), 522-532.

11. Ding, Q.B., Ainsworth, P., Plunkett, A., Tucker, G., Marson, H. (2006). The effect of extrusion conditions on the functional and physical properties of wheat-based expanded snacks. Journal of Food Engineering, 73, 142-148.

12. Ding, Q-B., Ainsworth, P., Tucker, G., Marson, $H$. (2005). The effect of extrusion conditions on the physicochemical properties and sensory characteristics of rice-based expanded snacks. Journal of Food Engineering, 66, 283-289.

13. FAOSTAT (2017). FAOSTAT Data-Countries by commodity. Food and Agricultural Organization of the United Nations. (Retrieved October 29, 2018 from http://www.fao.org/faostat/en/\#rankings/countrie s by commodity).

14. Filli, K.B., Nkama, I., Jideani, V.A., Abubakar, U.M. (2012). The effect of extrusion conditions on the physicochemical properties and sensory characteristics of millet - cowpea based fura. European Journal of Food Research and Review, 2 (1), 1-23.

15. García-Niño, W.R., Zazueta, C. (2015). Ellagic acid: Pharmacological activities and molecular mechanisms involved in liver protection. Pharmacological Research, 97, 84-103.

16. Gođevac, D., Tešević, V., Vajs, V., Milosavljević, S., Stanković, M. (2009). Antioxidant properties of raspberry seed extracts on micronucleus distribution in peripheral blood lymphocytes. Food and Chemical Toxicology, 47, 2853-2859.

17. Gujral, H.S., Singh, N., Singh, B. (2001). Extrusion behaviour of grits from flint and sweet corn. Food Chemistry, 74, 303-308.

18. Hagenimana, A., Ding, X.L., Fang, T. (2006). Evaluation of rice flour modified by extrusion cooking. Journal of Cereal Science, 43, 38-46.

19. Hakkinnen, S.H., Karenlampi, S.O., Mykkanen, H.M., Heinone, I.M., Torronen, A.R. (2000 A). Ellagic acid content in berries: Influence of domestic processing and storage. European Food Research and Technology, 212, 75-80.

20. Han, D.H., Lee, M.J., Kim, J.H. (2006). Antioxidant and apoptosis-inducing activities of ellagic acid. Anticancer Research, 26, 36013606.

21. Harris, G.K. Gupta, A., Nines, R.G., Kresty, L.A., Habib, S.G., Frankel, W.L., La Perle, K., Gallaher, D.D., Schwartz, S.J., Stoner, G.D. (2001). Effects of lyophilized black raspberries on azoxymethane-induced colon cancer and 8hydroxy-2'-deoxyguanosine levels in the $\mathrm{Fi}$ scher 344 Rat. Nutrition and Cancer, 40 (2), 125-33.

22. Jaekel, L. Z., Schmiele, M., da Silva Rodrigues, R., Chang, Y.K. (2015). Influence of the extrusion process on the technological properties of hydroxypropylated cross-linked cassava starch. Journal of Food Science and Technology, 52 (11), 7305-7312.

23. Juranic, Z., Zizak, Z., Tasic, S., Petrovic, S., Nidzovic, S., Leposavic, A., Stanojkovic, T. (2005). Antiproliferative action of water extracts of seeds or pulp of five different raspberry cultivars. Food Chemistry, 93, 39-45.

24. Kapelko, M., Zięba, T., Gryszkin, A., Styczyńska, M., Wilczak, A. (2013). Properties of retrograded and acetylated starch produced via starch extrusion or starch hydrolysis with pullulannase. Carbohydrate Polymers, 97, 551557.

25. Kassim, M., Achoui, M., Mustafa, M.R., Ali Mohd, M., Yusoff, K.M. (2010). Ellagic acid, 
phenolic acids, and flavonoids in Malaysian honey extracts demonstrate in vitro anti-inflammatory activity. Nutrition Research, 30 (9), 650659.

26. Kaur, A., Kaur, S., Singh, M., Singh, N., Shevkani, K., Singh, B. (2015). Effect of banana flour, screw speed and temperature on extrusion behaviour of corn extrudates. Journal of Food Science and Technology, 52 (7), 4276-4285.

27. Korus, J., Gumul, D., Czechowska, K. (2007). Effect of extrusion on the phenolic composition and antioxidant activity of dry beans of Phaseolus vulgaris I. Food Technology and Biotechnology, 45 (2), 139-146.

28. Kosmala, M., Zduńczyk, Z., Juśkiewicz, J., Jurgoński, A., Karlińska, E., Macierzyński, J., Jańczak, R., Rój, E. (2015). Chemical composition of defatted strawberry and raspberry seeds and the effect of These dietary ingredients on polyphenol metabolites, intestinal function, and selected serum parameters in rats. Journal of Agricultural and Food Chemistry, 63, 29892996.

29. Kristiawan, M., Chaunier, L., Della Valle, G., Ndiaye, A., Vergnes, B. (2016). Modeling of starchy melts expansion by extrusion. Trends in Food Science and Technology, 48, 13-26.

30. Kumar, N., Sarkar, B.C., Sharma, H.K. (2010). Development and characterization of extruded product of carrot pomace, rice flour and pulse powder. African Journal of Food Science, 4, 703-717.

31. Landete, J.M. (2011). Ellagitannins, ellagic acid and their derived metabolites: a review about source, metabolism, functions and health. Food Research International, 44, 1150-1160.

32. Larrosa, M., Garcia-Conesa, M.T., Espina, J.C, Tomas-Barberan, F.A. (2010). Ellagitannins, ellagic acid and vascular health. Molecular Aspects of Medicine, 31, 513-539.

33. Lazou, A., Krokida, M. (2010). Structural and textural characterization of corn-lentil extruded snacks. Journal of Food Engineering, 100 (3), 392-408.

34. Li, S.-Q., Zhang, H.Q., Tony Jin, Z., Hsieh, F.H. (2005). Textural modification of soya bean/corn extrudates as affected by moisture content, screw speed and soya bean concentration. International Journal of Food Science and Technology, 40 (7), 731-741.

35. Miller, R., Mulvaney, S. (2000). Extrusion and extruders. In Breakfast cereals, and how they are made. Eds. R. Fast, E. Cadwell, American Association of Cereal Chemist, St. Paul, pp. 215-278.

36. Mullen, W., McGinn, J., Lean M.E., MacLean, M.R., Gardner, P., Duthie, G.G. (2002). Ellagitannins, flavonoids, and other phenolics in red raspberries and their contribution to antioxidant capacity and vasorelaxation properties. Journal of Agricultural Food Chemistry, 50, 5191-5196.

37. Muthukumaran, S., Tranchant, C., Shi, J., Ye, X., Xue, S.J. (2017). Ellagic acid in strawberry (Fragaria spp.): Biological, technological, sta- bility, and human health aspects. Food Quality and Safety, 1 (4), 227-252.

38. Navale, S.A., Swami, B.S., Thakor, N.J. (2015). Extrusion cooking technology for foods: A review. Journal of Ready to Eat Food, 2, 66-80.

39. Nile, S.H., Park, S.V. (2014). Edible berries: Review on bioactive components and their effect on human health. Nutrition, 30, 134-144

40. O'Neil, M.J. (Ed.) (2006). The Merck Index. An Encyclopedia of Chemicals, Drugs and Biologicals. Merck Inc., Whitehouse Station, NJ, USA.

41. Paredes-López, O., Cervantes-Ceja, L.M., Vigna-Perez, M., Hernandez-Perez, T. (2010). Berries: improving human health aging, and promoting quality life-a review. Plant Foods for Human Nutrition, 65, 299-308.

42. Repo-Carrasco-Valencia, R., De La Cruz, A.A., Alvarez, J.C.I., Kallio, H. (2009a). Chemical and functional characterization of kaiwa (Chenopodium pallidicaule) grain, extrudate and bran. Plant Foods for Human Nutrition, 64 (2), 94101.

43. Repo-Carrasco-Valencia, R., Pena, J., Kallio, H., Salminen, S. (2009b). Dietary fiber and other functional components in two varieties of crude and extruded kiwicha (Amaranthus caudatus). Journal of Cereal Science, 49 (2), 219-224.

44. Rios de Souza, V., Pereira, P.A.P., Da Silva, T.T.L., Lima, L.C.O., Pio, R., Queiroz, F. (2014). Determination of the bioactive compounds, antioxidant activity and chemical composition of Brazilian blackberry, red raspberry, strawberry, blueberry and sweet cherry fruits. Food Chemistry, 156, 362-368.

45. Robin, F., Dubois, C., Pineau, N., Schuchmann, P.H., Plazer, S. (2011). Expansion mechanism of extruded foams supplemented with wheat bran. Journal of Food Engineering, 107 (1), 8089

46. Rodríguez-Miranda, J., Ruiz-López, I.I., Herman-Lara, E., Martínez-Sánchez, C.E., Delgado-Licon, E., Vivar-Vera, M.A. (2011). Development of extruded snacks using taro (Colocasia esculenta) and nixtamalized maize (Zea mays) flour blends. LWT - Food Science and Technology, 44, 673-680.

47. Singh, B., Sekhon, K.S., Singh, N. (2007). Effects of moisture, temperature and level of pea grits on extrusion behaviour and product characteristics of rice. Food Chemistry, 100, 198202.

48. Stojceska, V., Ainsworth, P., Plunkett, A., Íbanoğlu, Ş. (2009). The effect of extrusion cooking using different water feed rates on the quality of ready-to-eat snacks made from food by-products. Food Chemistry, 114 (1), 226-232.

49. Svihus, B., Kløvstad, K.H., Perez, V., Zimonja, O., Sahlström, S., Schuller, R.B., Jeksrud, W.K., Prestløkken, E. (2004). Physical and nutritional effects of pelleting of broiler chicken diets made from wheat ground to different coarsenesses by the use of roller mill and hammer mill. Animal Feed Science and Technology, 117, 281-293. 
50. Szajdek, A., Borowska, E.J. (2008). Bioactive compounds and health-promoting properties of berry fruits: A review. Plant Foods for Human Nutrition, 63 (4), 147-156.

51. Thachil, T.M., Chouksey, K.M., Gudipati, V. (2013). Amylose-lipid complex formation during extrusion cooking: effect of added lipid type and amylose level on corn-based puffed snacks. International Journal of Food Science and Technology, 49 (2), 309-316.

52. Thymi, S., Krokida, M.K., Pappa, A., Maroulis, Z.B. (2005). Structural properties of extruded corn starch. Journal of Food Engineering, 68 (4), 519-526.

53. Usta C., Ozdemir S., Schiariti M., Pudd P.E. (2013). The pharmacological use of ellagic acid-rich pomegranate fruit. International Journal of Food Sciences and Nutrition, 64, 907913.

54. Wada L., Ou B. (2002). Antioxidant activity and phenolic content of Oregon caneberries. Journal of Agricultural Food Chemistry, 50, 34953500 .
55. Yağci, S., Göğüs, F. (2009). Effect of incorporation of various food by-products on some nutritional properties of rice-based extruded foods. Food Science and Technology International, 15 (6), 571-581.

56. Yu. L., Moore. J. (2007). Methods of making and using nutritional compositions. United States Patent Application Publication, US 2007/0184164 A1.

57. Zafrilla, P., Ferreres, F., Tomas-Barberan, F.A. (2001). Effect of processing and storage on the antioxidant ellagic acid derivatives and flavonoids of red raspberry (Rubusidaeus) jams. Journal of Agricultural Food Chemistry, 49, 3651-3655.

58. Zhu, L-J., Shukri, R., De Mesa-Stonestreet, N.J., Alavi, S., Dogan, H., Shi, Y.-C. (2010). Mechanical and microstructural properties of soy protein - high amylose corn starch extrudates in relation to physiochemical changes of starch during extrusion. Journal of Food Engineering, 100, 232-238.

\title{
ФИЗИЧКО-ХЕМИЈСКЕ ОСОБИНЕ КУКУРУЗНОГ ЕКСТРУДАТА ОБОГАЋЕНОГ СЕМЕНОМ МАЛИНЕ
}

\author{
Јелена Н. Перовић, Бошко Д. Марић, Немања В. Теслић, Јована С. Којић, Јелена А. Круљ, \\ Бојана В. Филипчев, Небојша М. Илић
}

\begin{abstract}
Универзитет у Новом Саду, Научни институт за прехрамбене технологије у Новом Саду, 21000 Нови Сад, Булевар цара Лазара 1, Србија
\end{abstract}

Сажетак: Истраживања су спроведена како би се утврдио утицај услова екструдирања на физичко-хемијске особине кукурузног екструдата са додатком семена малине. Семе малине богато је елагинском киселином, природним фенолним антиоксидантом који има благотворан ефекат на здравље људи. Екструдати су припремљени помоћу лабораторијског једнопужног екструдера при различитим условима рада. Бокс-Бенкен експериментални дизајн коришћен је за дефинисање варијација садржаја влаге (18-25\%), температуре екструдирања $\left(100-200{ }^{\circ} \mathrm{C}\right)$ и садржаја семена малине (0-20\%) на индекс експанзије, тврдоћу и садржај елагинске киселине. Садржај влаге од $18 \%$, температура од $150{ }^{\circ} \mathrm{C}$ и $0 \%$ семена малине условили су настанак екструдата са највећим експанзионим индексом $(2,15)$. Највећи садржај елагинске киселине забележен је у узорку са $20 \%$ семена малине $(609,54 \mathrm{mg} / \mathrm{kg})$ екструдираном при условима од $100{ }^{\circ} \mathrm{C}$ и $21,5 \%$ влаге. Екструдати добијени при условима $0 \%$ семена малине, температура екструдирања од $100{ }^{\circ} \mathrm{C}$ и 21,5\% влаге показали су највећу тврдоћу $(53,34 \mathrm{~kg})$. Закључено је да промена једног или више параметара у процесу екструдирања може значајно утицати на карактеристике добијеног производа и да семе малине има велики потенцијал у обогаћивању хране.

Кључне речи: кукурузна крупица, семе малине, екструдирање, елагинска киселина, индекс експанзије, тврдоћа

Received: 25 February 2019

Received in revised form: 10 April 2019

Accepted: 17 April 2019 